\section{Homozygous, Monoecious, Virescent Melon C879-J3}

\author{
Perry E. Nugent ${ }^{1}$ \\ U.S. Vegetable Laboratory, Agricultural Research Service, U.S. Department \\ of Agriculture, 2875 Savannah Highway, Charleston, SC 29414
}

Additional index words. muskmelon, cantaloupe, Cucumis melo, genetic marker, seedling marker, disease resistance

The discovery of a melon virescent (Cucumis melo L.) marker in a 1967 field nursery led to the development and release of C879-J1 and J2 germplasm in 1984 (Nugent, 1987). At that time, C879-J2 was segregating for monoecious $(A)$ and andromonoecious $(a)$ flowering habits. Line C879-J3 was developed from C879-J2 through six generations of selection for uniform flowering and fruit type. It was approved for release in 1991 by the Agricultural Research Service, U.S. Dept. of Agriculture. C879-J3 supplies public and private muskmelon breeders with improved homozygous, monoecious, virescent germplasm for developing inbred lines and hybrid cultivars.

\section{Origin}

The virescent marker line was developed from a complex series of crosses and selections involving the cultivars Mainstream, 'Rocky Ford, Netted Gem, PMR 450, Hearts of Gold, Planters Jumbo, Georgia 47, and PMR 6 and plant introductions 124111, 124112, 164323, and 193495 (Hoffman and Nugent, 1973; Nugent, 1987). The original plant was discovered by C.F. Andrus in a field nursery in 1968, given the accession number C879, and increased by self-pollination. These original mutant seedlings (1969) were chlorophylldeficient, and $95 \%$ of them died. The surviving seedlings developed chlorophyll slowly but grew into nearly normal plants. I made phenotypic selections and intercrosses to improve its horticultural quality and to add the monoecious flowering habit. C879-J1 and J2 were selected from C879 made in 1984. Subsequently, C879-J3, a homozygous, monoecious-flowering segregant, was selected from C879-J2 in 1989, after five cycles of fruit-torow recurrent selection for flowering habit.

\section{Description}

Plants of C879-J2 have survival rates of $75 \%$ to $80 \%$ and produce several $1.6-\mathrm{kg}$, oval, $14 \times 16.5-\mathrm{cm}$, high-quality sutured fruit. Their cream-colored flowers fade to white and have

\footnotetext{
Received for publication 25 Feb. 1993. Accepted for publication 6 Aug. 1993. The cost of publishing this paper was defrayed in part by the payment of page charges. Under postal regulations, this paper therefore must be hereby marked advertisement solely to indicate this fact.

${ }^{1}$ Research Horticulturist.
}

yellow centers and orange stigmas. Yields of these C879-J2 plants are similar to the highyielding parent cultivar Mainstream, with four to eight fruit per plant. C879-J3 fruit (Fig. 1) have a unique yellow flesh, with occasional orange streaks, which may be attributed to the virescent gene. C879-J3 is highly resistant to powdery mildew [Sphaerotheca fuliginea (Schlecht ex. Fr.) Poll.] and moderately resistant (reaction type 2) to downy mildew [Pseudoperonospora cubensis (Berk. \&Curt.) Rostow] under natural epiphytotic conditions at Charleston, S.C.

\section{Uses}

This virescent mutant (Hoffman and Nugent, 1973; Nugent, 1987) has been used in gene-flow and pollination studies (Handel, 1982; Nugent and Hoffman, 1981) and in hybrid-seed production and species-crossing studies (Nugent, 1980, 1984; Nugent and Bhella, 1988). We have been using this line as a labor-saving device since 1969. Many hybrid seedlings can be produced in isolation (at least $150 \mathrm{~m}$ from any other melon) when 15$\mathrm{m}$-long pollinator rows are alternated with virescent marker rows. When seed harvested from the fruit of virescent plants are planted, at least $5 \%$ of the seedlings are normal green, which indicates that they are hybrids. C879-J3 produces an average of $8 \%$ hybrid seedlings, with a low of $0 \%$ and a high of $47 \%$. $\mathrm{cm}$, and length, $16.5 \mathrm{~cm}$

\section{Culture}

Because of the weak initial growth, direct seeding in field plots is not recommended. To ensure survival of virescent seedlings, seed should be sown in cellpacks or peat-pellets. A recent experiment showed that when C879-J3 seed were planted in Accelerated Propagation System-24 (Gardener's Supply Co., Burlington,Vt.) and filled with Metro-Mix 360 (GraceSierra, Milpitas, Calif.), seedlings were ready for transplanting in 2 weeks. With other procedures, growth is delayed by 7 to 10 days as compared to other lines.

\section{Availability}

Samples of this accession are available from P.E.N. on a pro-rata basis to breeders and other scientists. Seed recipients are asked to give appropriate recognition of the germplasm source if it is used in developing a new germplasm, parental line, or cultivar.

\section{Literature Cited}

Handel, S.N. 1982. Dynamics of gene flow in an experimental population of Cucumis melo (Cucurbitaceae). Amer. J. Bet. 69(10):15381546.

Hoffman, J.C. and P.E. Nugent. 1973. Inheritance of a virescent mutant in muskmelon. J. Hered. 64:311-316.

Nugent, P.E. 1980. The genetic relationship of virescent, yellow-green, glabrous, and halo mutants in muskmelon. HortScience 15:804-805.

Nugent, P.E. 1984. The virescent marker as a breeding tool in muskmelon. HortScience 19:211. (Abstr.)

Nugent, P.E. 1987. C879-J1 and C879-J2 virescent mutant muskmelon breeding lines. HortScience 22(2):333-335.

Nugent, P.E. and H.S. Bhella. 1988. Anew chlorotic mutant of muskmelon. HortScience 23(2):379381.

Nugent, P.E. and J.C. Hoffman. 1981. Natural cross pollination in four andromonoecious seedling marker lines of muskmelon. HortScience 16:7374.

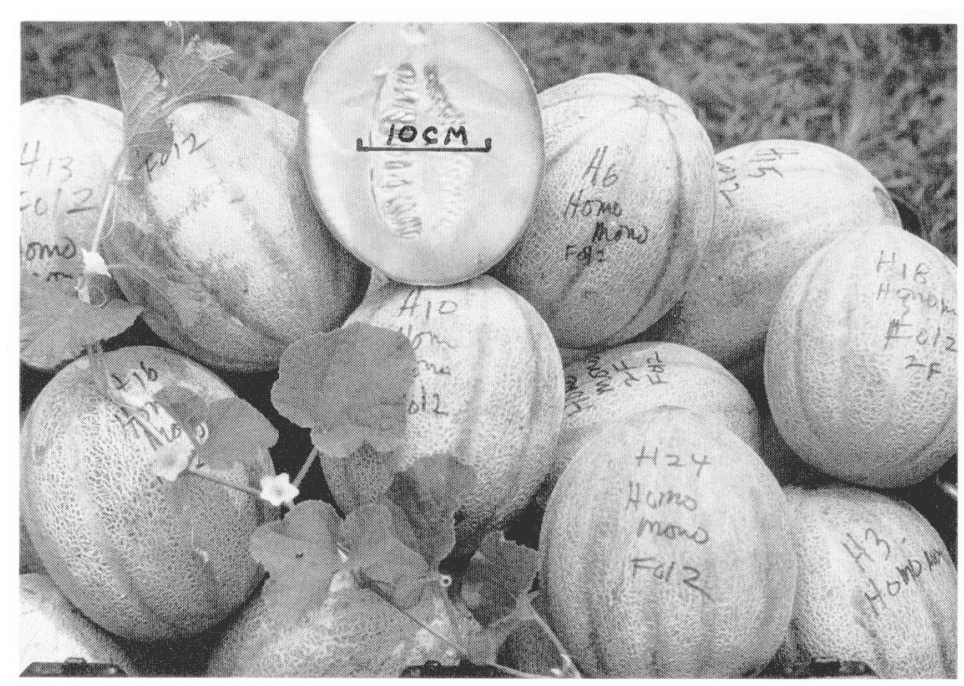

Fig. 1. Vine, flowers, and fruit of the C879-J3 melon line. Means were fruit weight, $1.6 \mathrm{~kg}$; diameter, 14.0 